\title{
EKSTRAKSI TANIN DARI KULIT KAYU AKASIA DENGAN MENGGUNAKAN MICROWAVE: PENGARUH DAYA MICROWAVE, WAKTU EKSTRAKSI DAN JENIS PELARUT
}

\section{EXTRACTION OF TANNIN FROM ACACIA BARK USING MICROWAVE: IMPACT OF POWER OF MICROWAVE, EXTRACTION TIME AND SOLVENT}

\author{
Iriany, Florentina Pandiangan*, Christina Eka P \\ Departemen Teknik Kimia, Fakultas Teknik, Universitas Sumatera Utara \\ Pusat Unggulan Produk Natural Berbasis Teknologi \\ Jl. Almamater Kampus USU Medan 20155, Indonesia \\ *Email: flopandiangan94@gmail.com
}

\begin{abstract}
Abstrak
Kulit kayu akasia diekstraksi untuk memperoleh senyawa tanin yang akan digunakan sebagai adsorben pada larutan logam $\mathrm{Cd}$ dan $\mathrm{Cu}$. Penelitian ini bertujuan untuk melihat pengaruh daya microwave, waktu ekstraksi dan jenis pelarut pada ekstraksi tanin dengan metode microwave-assisted extraction untuk memaksimalkan tanin yang diperoleh. Tanin tersebut diaplikasikan sebagai adsorben dari bahan alam dalam penjerapan logam $\mathrm{Cd}$ dan $\mathrm{Cu}$. Proses yang digunakan dalam penelitian ini adalah ekstraksi padat cair dengan metode microwave-assisted extraction menggunakan pelarut aquadest dan etanol dengan daya micreowave $100 \mathrm{~W}, 180 \mathrm{~W}, 300 \mathrm{~W}, 450 \mathrm{~W}$, dan $600 \mathrm{~W}$ dan waktu ekstraksi 1 menit, 3 menit dan 5 menit. Hasil ekstraksi dianalisis dengan spektrofotometer UV-Vis. Selanjutnya ekstrak dengan yield tanin tertinggi dimanfaatkan sebagai adsorben untuk menjerap logam $\mathrm{Cd}$ dan $\mathrm{Cu}$. Konsentrasi logam $\mathrm{Cd}$ dan $\mathrm{Cu}$ dianalisis menggunakan Atomic Absorption Spectrophotometer. Hasil penelitian menunjukkan yield tanin tertinggi $26,606 \mathrm{mg} / \mathrm{g}$ pada daya microwave $100 \mathrm{~W}$ dan waktu ekstraksi 3 menit dengan pelarut etanol. Adsorben dari tanin dapat menjerap logam dengan kapasitas adsorpsi pada $\mathrm{Cd}$ dan $\mathrm{Cu}$ sebesar $3,81 \mathrm{mg} / \mathrm{g}$ dan $2,26 \mathrm{mg} / \mathrm{g}$.
\end{abstract}

Kata kunci: tanin, ekstraksi, adsorpsi, logam berat, kulit akasia

\begin{abstract}
Tannin is one of complex polyphenol compound which soluble in polar solvent. Tannin could be extracted from acacia bark. This study aims to examine microwave-assisted extraction of tannins under influence of microwave power, extraction time, and solvent and its application to adsorb $\mathrm{Cd}$ and $\mathrm{Cu}$. Tannin was extracted from acacia bark with feed-to-solvent ratio $(1: 20 \mathrm{~g} / \mathrm{ml})$. Power of microwave was adjusted $100 \mathrm{~W}, 180 \mathrm{~W}, 300 \mathrm{~W}, 450 \mathrm{~W}$, and $600 \mathrm{~W}$ for 1 minute, 3 minutes and 5 minutes respectively using aquadest and ethanol as the solvent. The extracts were analyzed using UV-Vis spectrophotometer. Furthermore, the extract with the highest yield of tannins are used as the adsorbent. The concentration of Cd and cu were analyzed using Atomic Absorption Spectrophotometer. The result showed the highest yield of tannin $26.606 \mathrm{mg} / \mathrm{g}$ at $100 \mathrm{~W}$ and 3 minutes extraction time using ethanol as the solvent. The result showed that the adsorption capacity of adsorbent from tannin was $3.81 \mathrm{mg} / \mathrm{g}$ and $2.26 \mathrm{mg} / \mathrm{g}$ for $\mathrm{Cd}$ and $\mathrm{Cu}$ respectively.
\end{abstract}

Keywords : tannin, extraction, adsorption, heavy metal, acacia bark

\section{Pendahuluan}

Tanin termasuk senyawa polifenol kompleks yang dapat larut di dalam berbagai pelarut polar seperti aquadest, etanol, metanol, dan aseton $[1,7]$. Tanin yang terdapat pada kulit kayu akasia dapat diperoleh melalui proses ekstraksi. Metode ekstraksi dengan bantuan microwave digunakan karena memiliki keunggulan seperti waktu ekstraksi relatif lebih singkat, massa sampel yang digunakan lebih sedikit dan jumlah pelarut yang digunakan lebih sedikit. Selain itu, metode ekstraksi dengan bantuan microwave menghasilkan yield yang lebih banyak [11].

Tanin yang berasal dari bahan alam telah banyak dikembangkan menjadi adsorben karena ramah lingkungan [14]. Adanya kandungan fenolik pada tanin menunjukkan afinitas yang tinggi pada berbagai ion logam [9], sehingga adsorben ini dapat dimanfaatkan untuk menadsorpsi logam berat seperti $\mathrm{Pb}, \mathrm{Cu}, \mathrm{Cd}$, dan $\mathrm{Pd}$ dan pada pengolahan air seperti penghilangan zat warna maupun deterjen $[3,14]$.

Pada penelitian ini tanin dari kulit kayu akasia diekstraksi dengan bantuan microwave dengan menvariasikan daya microwave yang digunakan, waktu ekstraksi dan jenis pelarut untuk mendapatkan yield tanin tertinggi. Tanin dari hasil ekstraksi ini kemudian dimanfaatkan menjadi adsorben pada proses adsorpsi logam kadmium $(\mathrm{Cd})$ dan tembaga $(\mathrm{Cu})$. 


\section{Teori}

Tumbuhan akasia (Acacia mangium willd) adalah salah satu jenis pohon cepat tumbuh. Kulit pohon akasia yang masih muda memiliki permukaan yang halus dan berwarna kehijauan sedangkan kulit pohon tua memiliki tekstur yang lebih kasar dan berwarna cokelat gelap [13].

Akasia merupakan salah satu jenis tanaman yang memiliki kadar tanin yang tinggi, yaitu berkisar antara 15-50\% dari bobot kering Tanin merupakan salah satu bahan pembuatan adsorben yang baik [14]. Tanin dapat diklasifikasikan menjadi dua jenis berdasarkan bentuknya seperti pada gambar 1 yaitu hydrolyzable tannin (tanin terhidrolisis) dan condensed tannin (tanin terkondensasi) [10].

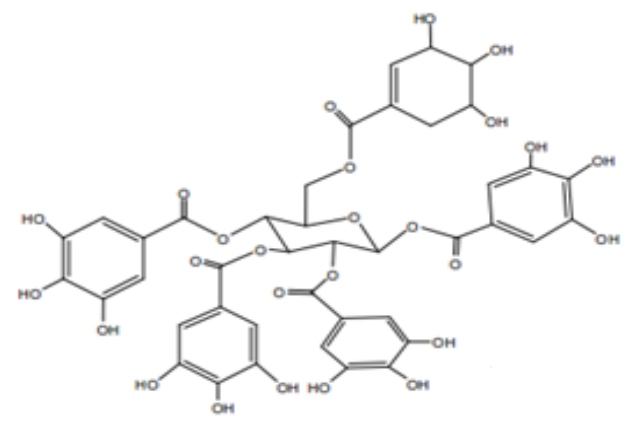

(a)

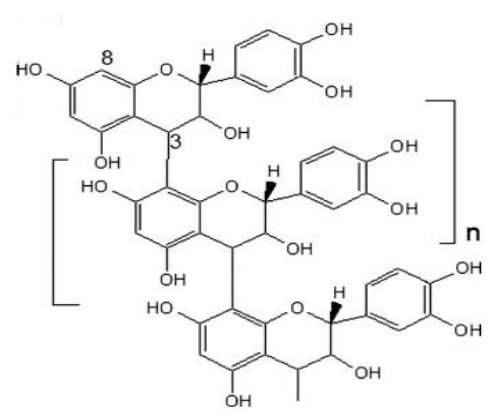

(b)

Gambar 1. Struktur (a) tanin terhidrolisis dan (b) tanin terkondensasi

Proses ekstraksi tanin dari kulit kayu aksia dengan bantuan microwave lebih cepat, aman dan lebih ramah lingkungan dibandingkan metode ekstraksi konvensional [13]. Ada beberapa faktor yang perlu diperhatikan pada proses ekstraksi dengan microwave, antara lain daya microwave, waktu ekstraksi, jenis pelarut, dan perbandingan padatan dengan pelarut [7]. Penentuan daya pada metode microwave harus disesuaikan dengan titik didih dari pelarut yang digunakan [11]. Pemakaian daya yang terlalu besar dapat menyebabkan degradasi pada struktur dan kualitas dari ekstak yang dihasilkan. Pada proses ekstraksi semakin lama waktu ekstraksi, maka semakin banyak ekstrak yang akan dihasilkan [7].
Pada ekstraksi dengan bantuan microwave, pelarut dari digunakan harus mampu menyerap gelombang mikro, biasanya senyawa polar sangat baik dalam menyerap energi dari gelombang mikro [6].

Adsorpsi (penjerapan) adalah suatu proses pemisahan dimana komponen dari suatu fase fluida berpindah ke permukaan zat padat yang menjerap (adsorben). Proses adsorpsi tergantung pada sifat zat padat yang mengadsorpsi, sifat atom/molekul yang dijerap, konsentrasi, temperatur, dan lain-lain [12]. Adsorpsi telah banyak diaplikasikan dalam proses pengolahan air dan pemulihan senyawa logam mulia karena ramah lingkungan. Tanin memiliki potensi yang cukup baik untuk dimanfaatkan sebagai adsorben $[5,9]$.

\section{Metodologi Penelitian \\ Bahan Baku dan Peralatan}

Bahan baku utama dalam penelitian ini adalah serbuk kulit kayu akasia, aquadest, etanol $\mathrm{CuSO}_{4} .5 \mathrm{H}_{2} \mathrm{O}$ dan $\mathrm{CdCl}_{2} . \mathrm{H}_{2} \mathrm{O}$. Peralatan yang digunakan pada penelitian ini adalah microwave, hot plate, ayakan 50 mesh, corong, timbangan elektrik, termometer kertas saring, spektrofotometer UV-Vis, dan peralatan gelas.

\section{Pembuatan Serbuk Kulit Kayu Akasia}

Kulit kayu akasia dikeringkan sampai mencapai moisture content yang konstan, kemudian di- haluskan menggunakan ball mild lalu diayak dengan ayakan 50 mesh.

\section{Proses Ekstraksi Tanin dari Kulit Akasia}

Serbuk kulit akasia disiapkan sebanyak 1 gram lalu dicampurkan dengan $20 \mathrm{ml}$ pelarut (aquadest dan etanol ) kemudian dimasukkan ke dalam microwave selama 1 menit, 3 menit dan 5 menit dengan daya $100 \mathrm{~W}, 180 \mathrm{~W}, 300 \mathrm{~W}, 450$, dan 600 W. Kemudian dilakukan pengukuran suhu setelah proses ekstraksi. Ekstrak disaring untuk memisahkan filtrat dengan residu.

\section{Pembuatan Adsorben dari Tanin}

Ekstrak tanin sebanyak $25 \mathrm{ml} \mathrm{di-}$ campurkan dengan $5 \mathrm{~mL}$ asam klorida, lalu ditambahkan $10 \mathrm{~mL}$ formaldehid (HCHO) $37 \%$. Campuran larutan tersebut dipanaskan selama 30 menit. Endapan yang terbentuk dipisahkan dengan kertas saring lalu endapan dikeringkan.

\section{Proses Adsorpsi Logam Berat dengan Adsorben dari Tanin}

Disiapkan larutan $\mathrm{Cd}$ dan $\mathrm{Cu}$ masing masing dengan kadar $50 \mathrm{mg} / \mathrm{L}$. Lalu dicampurkan masing-masing 0,6 gram adsorben ke dalam 100 $\mathrm{ml}$ larutan logam. Proses adsorpsi berlangsung 
selama 180 menit dengan kecepatan putar 200 rpm pada suhu $50^{\circ} \mathrm{C}$.

\section{Hasil dan Pembahasan}

\section{Identifikasi Tanin pada Ekstrak Kulit Kayu} Akasia

Pada penelitian ini, tanin diekstraksi dari kulit kayu akasia dengan bantuan microwave. Hasil ekstraksi dari kulit kayu akasia perlu dianalisis secara kualitatif terlebih dahulu sebelum melakukan pengukuran kadar tanin dengan spectrofotometer UV-Vis [4]. Hasil analisis kualitatif dapat dilihat dari perubahan warna dan bentuk ekstrak. Uji kualitatif yang dilakukan yaitu pengujian dengan gelatin, kemudian dengan $\mathrm{FeCl}_{3}$ dan selanjutnya pengujian dengan $\mathrm{H}_{2} \mathrm{SO}_{4}$. Gambar 2 dan gambar 3 menunjukkan hasil uji kualitatif pada larutan ekstrak.

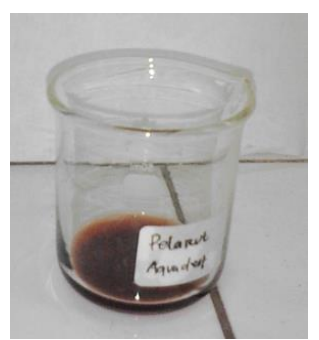

(a)

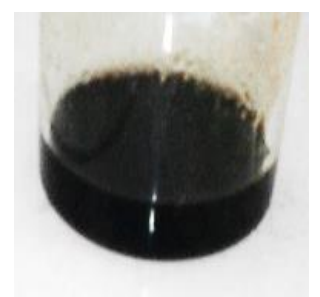

(c)

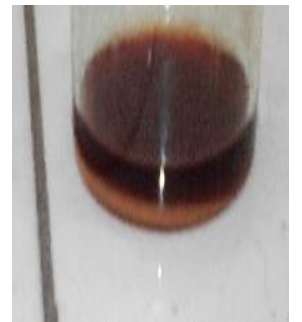

(b)

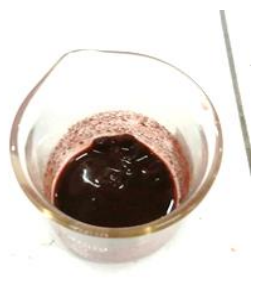

(d)
Gambar 2. Identifikasi Hasil Ekstrak dengan Pelarut Aquadest

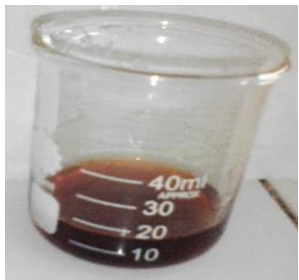

(a)

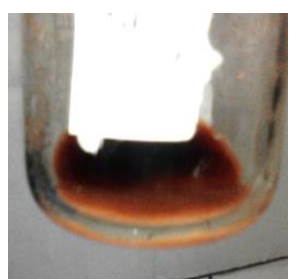

(b)

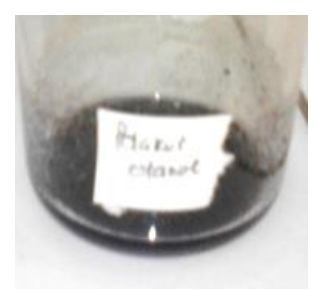

(c)

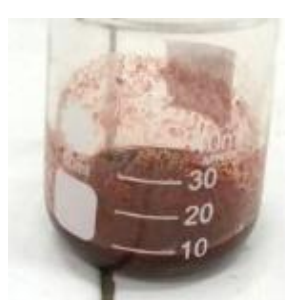

(d)

\section{Gambar 3. Identifikasi Hasil Ekstrak dengan Pelarut Aquadest}

Filtrat yang dicampurkan dengan gelatin menghasilkan endapan putih kekuningan (b). Endapan ini terbentuk karena tanin dapat menggumpalkan senyawa protein [8]. Selanjutnya saat penambahan $\mathrm{FeCl}_{3}$ pada sampel terjadi perubahan warna pada ekstrak dari coklat menjadi biru kehitaman (c). Perubahan warna ini disebabkan karena adanya reaksi antara senyawa fenol dengan $\mathrm{FeCl}_{3}$ yang membentuk senyawa kompleks [8]. Setelah itu ditambahkan $\mathrm{H}_{2} \mathrm{SO}_{4}$, perubahan yang terjadi adalah perubahan warna dari biru kehitaman menjadi coklat kemerahan selain itu terdapat endapan coklat (d). Semua perubahan fisik pada larutan ekstrak menunjukkan adanya senyawa tanin di dalam filtrat tersebut.

\section{Analisis Fourier Transformer-Infrared (Ft-Ir) pada Larutan Ekstrak Tanin}

Filtrat hasil ekstraksi dianalisis menggunakan FT-IR untuk melihat gugus yang terdapat pada ekstrak.

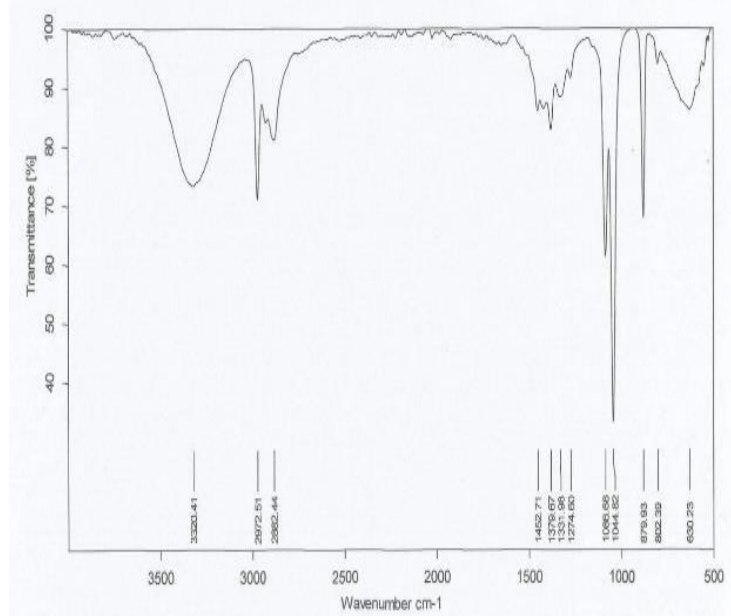

Gambar 4. Analisis FT-IR pada Larutan Ekstrak

Hasil analisis FT-IR pada gambar 4 menunjukkan adanya karakteristik tanin yaitu pada puncak vibrasi fenol $(-\mathrm{OH}) 3320,41 \mathrm{~cm}^{-1}$. Pada ekstrak tanin juga terdapat beberapa gugus, 
seperti gugus alkana $(-\mathrm{CH})$ pada puncak 2972,51-2882,44 $\mathrm{cm}^{-1}$, gugus aromatik $(\mathrm{C}=\mathrm{C})$ pada puncak $1452,71 \mathrm{~cm}^{-1}$, gugus fenol $(-\mathrm{OH})$ pada puncak 1379,67 $\mathrm{cm}^{-1}$, gugus senyawa nitro aromatik $\left(-\mathrm{C}-\mathrm{NO}_{2}\right)$ pada puncak $1331,98 \mathrm{~cm}^{-1}$, gugus eter (-CO) pada puncak 1274,60-1044,82 $\mathrm{cm}^{-1}$, gugus alkuna $(\mathrm{C} \equiv \mathrm{C})$ pada puncak 879,93 $802,39 \mathrm{~cm}^{-1}$, dan gugus senyawa lain $\left(\left(\mathrm{CH}_{2}\right) \mathrm{n}\right)$ pada puncak $630,23 \mathrm{~cm}^{-1}$.

\section{Pengaruh Daya Microwave Terhadap Suhu Ekstraksi}

Pada ekstraksi tanin dari kulit kayu akasia dengan bantuan microwave perlu dilakukan pengukuran suhu untuk melihat pengaruh daya terhadap profil suhu ekstraksi. Pengukuran suhu larutan ekstrak dilakukan sesaat setelah proses ekstraksi selesai. Gambar 5 menunjukkan pengaruh daya microwave terhadap suhu ekstrak dengan pelarut etanol dan aquadest.

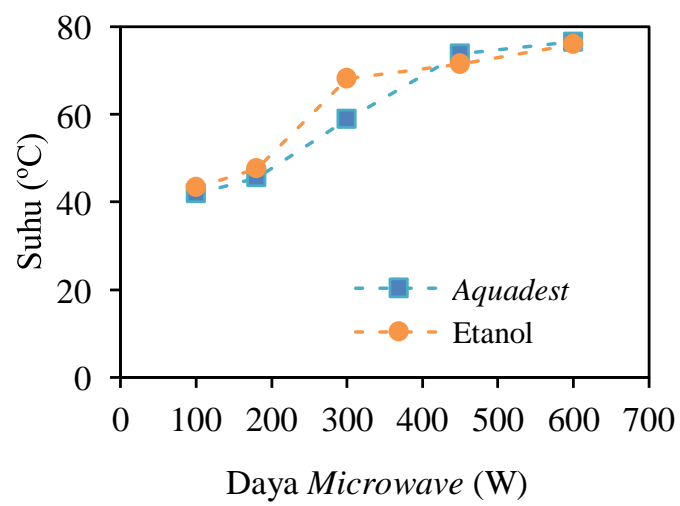
Gambar 5. Pengaruh Daya Microwave
terhadap Profil Suhu Ekstraksi

Daya microwave dan suhu ekstraksi saling terkait satu sama lain. Gelombang mikro dari microwave yang diserap oleh bahan dapat meningkatkan suhu larutan ekstrak. Semakin besar intensitas gelombang mikro yang diberikan menghasilkan panas yang lebih besar pada bahan yang menyebabkan suhu semakin meningkat. Meningkatnya suhu menyebabkan penurunan viskositas dan tegangan permukaan sedangkan kemampuan pelarut melarutkan bahan menjadi semakin baik. Namun penggunaan daya microwave yang terlalu besar menyebabkan suhu larutan menjadi terlalu tinggi mendekati titik didih pelarut sehingga akan ada pelarut yang menguap [9].

Profil suhu ekstrak dengan pelarut etanol dan aquadest pada waktu ekstraksi 1 menit meningkat seiring meningkatnya daya microwave yang digunakan selama proses ekstraksi. Hasil penelitian menunjukkan bahwa suhu sesaat setelah proses ekstraksi pada pelarut aquadest $42,0^{\circ} \mathrm{C}$ pada daya microwave $100 \mathrm{~W}$ dan meningkat menjadi $76,6^{\circ} \mathrm{C}$ saat daya microwave
$600 \mathrm{~W}$ dan pelarut etanol $43,5^{\circ} \mathrm{C}$ pada daya microwave $100 \mathrm{~W}$ dan meningkat menjadi $76,1^{\circ}$ $\mathrm{C}$ saat daya microwave $600 \mathrm{~W}$.

Suhu ektraksi yang meningkat menyebabkan adanya pelarut yang menguap karena mendekati titik didih pelarut. Titik didih pelarut aquadest $100^{\circ} \mathrm{C}$ sedangkan etanol $78,37^{\circ} \mathrm{C}$. Hal inilah yang menyebabkan adanya pelarut yang menguap sehingga ekstrak yang diperoleh berkurang.

\section{Pengaruh Daya Microwave, Waktu Ekstraksi dan Jenis Pelarut Terhadap Yield Tanin}

Daya microwave dan waktu ekstraksi merupakan kombinasi yang saling mempengaruhi. Pemilihan daya microwave dan waktu ekstraksi yang tepat dapat menghindari terjadinya degradasi termal pada bahan sehingga produk yang dihasilkan lebih maksimal [9]. Pemilihan pelarut yang tepat menjadi salah satu faktor yang sangat berpengaruh terhadap yield tanin yang akan dihasilkan $[11,13]$. Pelarut harus mampu menyerap gelombang mikro dan melarutkan senyawa yang diinginkan [9]. Tanin merupakan senyawa yang bersifat polar sehingga pelarut yang digunakan adalah pelarut polar. Pada penelitian ini digunakan aquadest dan etanol untuk melihat pengaruh jenis pelarut terhadap yield tanin yang diperoleh.

Gambar 6 menunjukkan hasil yield tanin yang diperoleh pada beberapa variasi daya microwave dan waktu ekstraksi dengan pelarut aquadest.

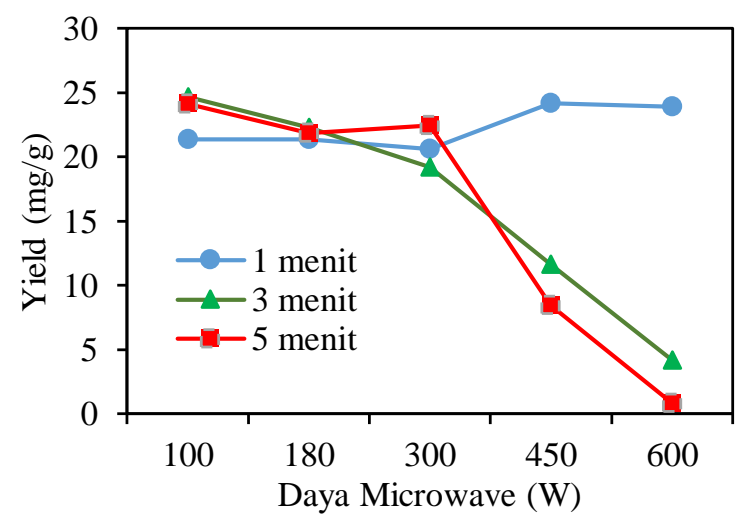

Gambar 6. Pengaruh Daya Microwave dan
Waktu Ekstraksi terhadap Yield Tanin
dengan Pelarut Aquadest

Berdasarkan hasil penelitian, yield tanin cenderung berkurang seiring bertambahnya daya microwave dan waktu ekstraksi. Yield tanin pada waktu ekstraksi 1 menit awalnya meningkat pada daya microwave yang rendah namun seiring meningkatnya daya microwave, yield tanin mulai menurun. Berbeda dengan yield yang diperoleh pada waktu ekstraksi 3 dan 5 menit yang 
cenderung mengalami penurunan seiring bertambahnya daya microwave. Pada waktu ekstraksi 5 menit, $600 \mathrm{~W}$ yield tanin menurun dratis menjadi $0,844 \mathrm{mg} / \mathrm{g}$.

Yield tanin yang cenderung menurun seiring bertambahnya daya microwave juga diperoleh pada pelarut etanol.

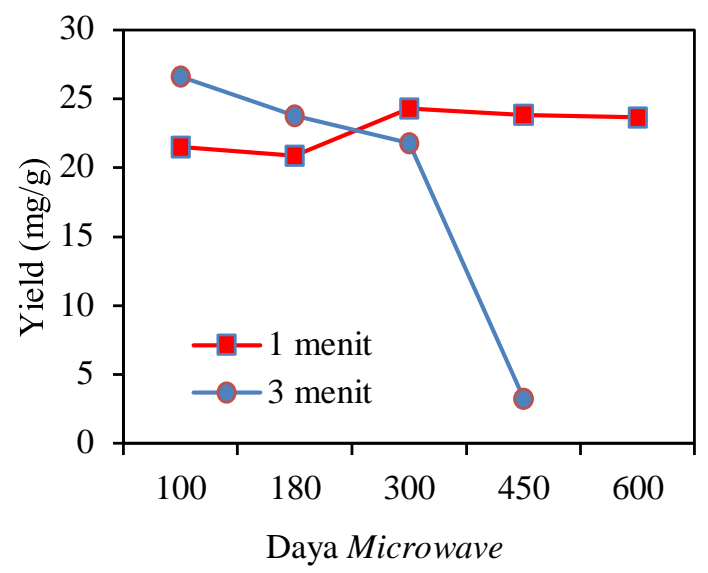

Gambar 7. Pengaruh Daya Microwave dan Waktu EKstraksi terhadap Yield Tanin dengan Pelarut Etanol

Berdasarkan gambar 7, yield tanin pada waktu ekstraksi 1 menit terus meningkat seiring bertambahnya daya microwave, namun sedikit menurun pada daya $600 \mathrm{~W}$, sedangkan pada waktu ekstraksi 3 menit yield tanin terus menurun seiring adanya

Pada variasi pelarut yang dibandingkan adalah yield tanin yang dihasilkan pada beberapa variasi daya microwave dan waktu. Jumlah yield yang dihasilkan dengan pelarut etanol lebih banyak dibandingkan dengan aquadest namun perbedaannya tidak terlalu signifikan, seiring meningkatnya daya microwave yang diberikan menyebabkan berkurangnya jumlah tanin yang dihasilkan.

Pelarut etanol merupakan pelarut yang baik untuk mengekstraksi senyawa polifenol dari bahan organik. Perbedaan yield antara pelarut aquadest dan etanol yang dihasilkan pada penelitian ini tidak terlalu signifikan. Berdasarkan hasil penelitian pada semua variasi yang telah dilakukan, yield terbanyak dihasilkan dengan pelarut etanol $26,606 \mathrm{mg} / \mathrm{g}$ pada daya microwave $100 \mathrm{~W}$ dengan waktu ekstraksi 3 menit, sedangkan dengan pelarut aquadest $24,666 \mathrm{mg} / \mathrm{g}$ pada daya microwave $100 \mathrm{~W}$ dan waktu ekstraksi 3 menit.

Penelitian yang telah dilakukan Naima, et al [11] menunjukkan bahwa ekstrak tanin dari kulit Acacia mollissima yang paling banyak diperoleh dengan menggunakan pelarut aquadest pada daya microwave $300 \mathrm{~W}$ selama 1 menit sebesar 47,64 $\mathrm{mg} / \mathrm{g}$. Perbedaan hasil penelitian ini dengan penelitian yang telah dilakukan Naima, et al [11] kemungkinan karena perbedaan jenis bahan baku yang digunakan, umur pohon, dan asal bahan baku yang disuplai.

\section{Analisis Scanning Electron Microscope (SEM) Pada Adsorben dari Tanin}

Pada penelitian ini dilakukan analisis scanning Electron Microscope (SEM) pada adsorben dari tanin untuk melihat permukaan dan pori pada adsorben. Suatu partikel dapat menjadi adsorben yang baik apabila memiliki pori pada permukaannya. Hasil analisis SEM pada gambar 8 menunjukkan adanya pori pada permukaan tanin sehingga dapat digunakan sebagai adsorben logam.

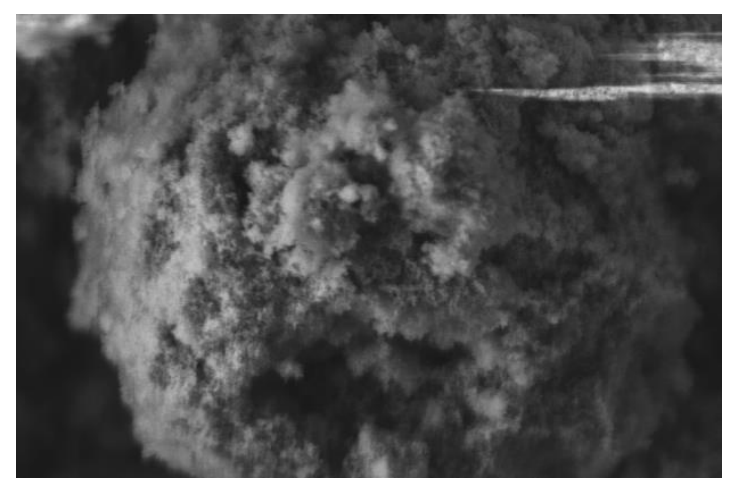

Gambar 8. Analisa SEM pada Tanin dari Kulit Kayu Akasia dengan Perbesaran 1000

\section{Analisis Kapasitas Penjerapan Logam Cd dan Cu Pada Adsorben Menggunakan Aas}

Adsorben yang berasal dari tanin menunjukkan afinitas yang baik dalam menjerap logam berat yang berasal dari limbah industri [5]. Mekanisme proses adsorpsi adalah proses saat suatu jenis molekul melepaskan ikatan dari larutannya dan menempel/terjerap pada permukaan adsorben akibat adanya proses kimia maupun fisika [1]. Adsorben dari tanin yang diperoleh dari hasil ekstraksi memiliki pori pada permukaannya seperti yang ditunjukkan pada hasil analisis SEM. Proses adsorpsi logam Cd dan $\mathrm{Cu}$ bertujuan untuk menguji kemampuan adsorpsi dari adsorben ini. Proses adsorpsi dilakukan pada kondisi asam dan suhu adsorpsi $50^{\circ} \mathrm{C}$ dengan kecepatan putar $200 \mathrm{rpm}$ selama 180 menit [12].

Berdasarkan hasil analisis menggunakan Atomic Absorption Spectrophotometer, konsentrasi awal larutan $\mathrm{Cd}$ sebelum adsorpsi 55,933 ppm dan menurun menjadi 33,072 ppm setelah proses adsorpsi. Kapasitas adsorpsi pada logam Cd 3,81 mg/gr dengan efisiensi adsorpsi 
40,872\%. Pada larutan $\mathrm{Cu}$ konsentrasi sebelum adsorpsi $67,438 \mathrm{ppm}$ dan menurun menjadi $53,814 \mathrm{ppm}$. Kapasitas adsorpsi pada logam $\mathrm{Cu}$ $2,26 \mathrm{mg} / \mathrm{gr}$ dengan efisiesi adsorpsi 20,20\%. Sehingga dapat disimpulkan bahwa senyawa tanin yang berasal dari ekstrak kulit kayu akasia dapat dimanfaatkan menjadi adsorben logam $\mathrm{Cd}$ maupun $\mathrm{Cu}$ karena konsentrasi logam menjadi berkurang setelah proses adsorpsi meskipun penjerapan logam tersebut belum maksimal.

\section{Kesimpulan}

Kesimpulan yang didapat dari penelitian ini adalah:

1. Hasil uji kualitatif dan FT-IR menunjukkan adanya senyawa tanin di dalam ekstrak kulit kayu akasia.

2. Penggunaan daya microwave yang terlalu besar dan waktu ekstraksi yang terlalu lama menyebabkan tanin hasil ekstraksi terdegradasi sehingga yield yang dihasilkan berkurang.

3. Yield tanin yang tertinggi diperoleh sebesar $26,606 \mathrm{mg} / \mathrm{g}$ pada daya microwave $100 \mathrm{~W}$ dan waktu ekstraksi 3 menit dengan pelarut etanol.

4. Adsorben dari ekstrak tanin dapat menjerap logam Cd yang terlarut dengan kapasitas adsorpsi $3,810 \mathrm{mg} / \mathrm{g}$ dan efisiensi adsorpsi $40,87 \%$, sedangkan pada logam Cu kapasitas adsorpsi $2,26 \mathrm{mg} / \mathrm{g}$ dengan efisiensi adsorpsi $20,20 \%$.

5. Adsorben dari tanin memiliki potensi untuk dikembangkan karena kemampuannya menjerap logam dan bahan baku yang ramah lingkungan.

\section{Daftar Pustaka}

[1] A. Kristianto, Pengaruh Ekstrak Kasar Tanin dari Daun Belimbing Wuluh (Averrhoa Bilimbi L.) pada Pengolahan Air, Skripsi, Universitas Jember, Jember, 2013.

[2] D. Kartikaningsih, M. A. Bachroni dan Y.C. Danarto, Pengambilan Tanin dari Kulit Kayu Bakau dan Pemanfaatannya sebagai Adsorben Logam Berat Cuprum $(\mathrm{Cu})$ dan Timbal $(\mathrm{Pb})$, Equilibrium, Vol. 13, No. 1 (2014) 23-27.

[3] E. Sieniawska dan T. Baj, Tannins Plant Metabolites: their Chemstry, Pharmacognosy, Lublin, 2017, p.199-232.

[4] F. Amalia, G. N. Afnani, A. Musfiroh, A. N. Fikriyani, S. Ucche, dan M. Murrukmihadi, Extraction and Stability Test of Anthocyanin from Buni Fruits (Antidesma bunius L.) as an Alternative Natural and Safe Food Colorants, J. Food Pharm. Sci, 1, (2013) 4953.
[5] H. A. M. Bacelo, S. C. R. Santos dan C. M. S. Botelho, Tannin Based Biosorbents for Environmental Applications - A Review, Chemical Engineering Journal, 303, (2016) 575-587.

[6] H. Krisnawati, M. Kallio, dan M. Kannien, Acacia Mangium Willd: Ecology, Silviculture and Productivity. Center for International Forestry Research, Bogor, Indonesia, 2010, p.15.

[7] Ismarani, Potensi Senyawa Tanin dalam Menunjang Produksi Ramah Lingkungan, Jurnal Agribisnis dan Pengembangan Wilayah, Vol. 3, No. 2, (2012) 46-55.

[8] L. Chupin, S.L. Maunu, S. Reynaud, A. Pizzi, B. Charrier, dan F.C. Bouhtoury, Characterisation of Maritime Pine (Pinus Pinaster) Bark Tannins Extracted under Different Conditions by Spectroscopic Methods, FTIR and HPLC, Industrial Crops and Products, 49, (2013) 897-903.

[9] P. C. Veggi, J. Martinez, dan M. Angela, M. Melreles, Microwave-Assisted Extraction for Bioactive Compounds Theory and Practice. Food Engineering, 2013, p. 240.

[10] Q. Yi, R. Fan, F. Xie, H. Min, Q. Zhang, dan Z. Luo, Selective Recovery of Au (III) and Pd (II) from Waste PCBs using Ethylenediamine Modified Persimmon Tannin Adsorbent, Procedia Environmental Sciences, 31, (2016) 185-194.

[11] R. Naima, M. Oumam, H. Hannache, A. Sesbou, B. Charrier, A. Pizzi, dan F.C. Bouhtoury, Comparison of the Impact of Different Extraction Methods on Polyphenols Yields and Tannins Extracted from Moroccan Acacia Mollissima Barks, Industrial Crops and Products, 70, (2015) 245-252.

[12] V. S. Munagapati, V. Yarramuthi, S. K. Nadavala, S. R. Alla, dan K. Abburi, Biosorption of $\mathrm{Cu}$ (II), $\mathrm{Cd}$ (II) and $\mathrm{Pb}$ (II) by Acacia Leucocephala Bark Powder: Kinetics, Equilibrium and Thermodynamics, Chemical Engineering Journal, 157, (2010) 357-365.

[13] X. Pan, G. Niu dan H. Liu, MicrowaveAssisted Extraction of Tea Polyphenols and Tea Caffeine from Green Tea Leaves, Chemical Engineering and Processing, 42, (2003) 129-133.

[14] Y. B. Hoong, A. Pizzi, P. M. Tahir, dan H. Pasch, Characterization of Acacia Mangium Polyflavonoid Tannins by MALDI-TOF Mass Spectrometry and $\mathrm{CPMAS}^{13} \mathrm{C}$ NMR, European Polymer Journal, 46, (2010) 1268-1277. 